\title{
O PLANO REAL E A REPÚBLICA RENTISTA
}

\section{THE REAL PLAN AND RENTIER REPUBLIC}

\author{
Matheus Bittencourt de Brito* \\ Ronaldo Herrlein Júnior ${ }^{* *}$
}

\begin{abstract}
RESUMO
A exposição que segue demonstra um dos problemas estruturais sobre os quais a economia brasileira se estabeleceu a partir da execução do último grande plano de estabilização, a saber, o Plano Real. A partir daí, ver-se-á que o modelo de estabilização referido nunca trouxe o prometido desenvolvimento sustentável, a despeito da sua eficácia no combate à inflação. Assim, o Plano Real só pode ser entendido em sua concretude por meio da consciência e análise crítica da realidade brasileira, isto é, pela noção de que o Brasil é um país dependente e subdesenvolvido. Desse modo, o Plano Real pode ser caracterizado com um pacto de classes no qual o setor financeiro tem o papel hegemônico. É por meio desta hegemonia que originar-se-á o caráter rentista da economia brasileira - ou seja, a República Rentista-, sobre o qual inicia-se o processo de superendividamento estatal e concentração financeira.
\end{abstract}

Palavras-chave: Plano Real; Desenvolvimento Sustentável; Pacto de Classe; República Rentista; Superendividamento Estatal;

\begin{abstract}
The following discussion demonstrates one of the structural problems in which the Brazilian economy was established from the implementation of the last major stabilization plan, the Real Plan. From this, it will be seen that the stabilization model referred to never brought the promised sustainable development, despite its effectiveness in combating inflation. Thus, the Real Plan can only be understood in its concreteness through the awareness and critical analysis of the Brazilian reality, that is, by the notion that Brazil is a dependent and underdeveloped country. Thus, the Real Plan can be characterized as a class pact in which the financial sector has the hegemonic role. It is through this hegemony that the rentier character of the Brazilian economy is born - that is, the Renegade Republic - upon which the process of state indebtedness and financial concentration begins.
\end{abstract}

Keywords: Real Plan; Sustainable development; Pact of Class; Rentier republic; Super Indebtedness state-owned;

\footnotetext{
"Economista pela Universidade Federal de Santa Catarina (UFSC). Mestrando em economia, com concentração em economia do desenvolvimento, no Programa de Pós-Graduação em Economia da Universidade Federal do Rio Grande do Sul (UFRGS).

"Doutor em Economia pela Universidade Estadual de Campinas (Unicamp). Professor do Departamento de Economia e Relações Internacionais da Universidade Federal do Rio Grande do Sul (UFRGS).
} 


\section{INTRODUÇÃO}

O Plano Real é considerado por Gustavo Franco como o plano que deu certo, o economista afirma na comemoração de 20 anos do plano que faria tudo de novo (FRANCO, 2014). O ex-presidente Fernando Henrique Cardoso - FHC - diz em entrevista que o plano foi uma demanda da sociedade brasileira (CARDOSO, 2009) No entanto, os instrumentos econômicos e políticos estão apenas no plano fenomênico da realidade, ou seja, a realidade concreta da inflação brasileira e sua história passam, necessariamente, pela investigação material da realidade social.

Assim, o Plano Real deve passar pela questão essencial de quais atores na sociedade brasileira, naquele período, estavam envolvidos e seriam afetados por tal plano. De tal forma que só é possível entender as necessidades e interesses por trás do Plano Real pelo reconhecimento de que este último está inserido numa totalidade econômica e política no Brasil e no mundo (NETTO, 2011). Portanto, é só quando se ultrapassa aparência do fenômeno - quando se busca conhecer a real natureza do Plano Real - que a ideia de uma moeda forte, de uma estabilidade permanente e da superação da inflação histórica brasileira, pode ser desmistificada e entendida como pura reprodução ideológica de uma falsa solução para a questão da estabilidade na economia brasileira.

Logo, o que pretendemos mostrar em nosso trabalho é o contexto histórico, ideológico e político na qual no Plano Real que insere, pois, para além do combate ao processo inflacionário, entendemos que o referido plano faz parte de uma lógica maior de institucionalização do rentismo. ${ }^{1}$ no Brasil. Tal fenômeno tem por base a nova natureza do capitalismo contemporâneo, isto é, a financeirização. Tal processo vem ganhando a cada dia mais a atenção dos cientistas sociais em geral - sobretudo dos economistas. O estudo do papel das finanças na lógica do modo de produção capitalista já tem sua semente plantada nas considerações que Marx faz acerca do capital portador de juros, no livro terceiro de $\mathrm{O}$

\footnotetext{
${ }^{1}$ Usaremos o conceito rentismo que é usado na literatura marxista. Dado o escopo deste trabalho, focar-nos-emos no conceito de renda vinculado ao sistema financeiro, a despeito de que a renda obtida pela propriedade da terra para fins agrícolas tornar seu proprietário um rentista - nos termos da literatura marxista. Assim, pois, o conceito de rentismo aqui utilizado vincula-se à seguinte noção: é a renda - juros e dividendos - que o capital monetário propicia a seu detentor pelo mero efeito de ele ser proprietário do mesmo (PAULANI, 2016).
}

Capital. Posteriormente, o desenvolvimento teórico e empírico do fenômeno da financeirização teve contribuições de diversas escolas do pensamento econômico até os dias atuais. Dentre as escolas do pensamento econômico com maiores contribuições ao estudo da financeirização no sistema capitalista, podemos citar três, a saber: a Escola Regulacionista Francesa, com autores como Michel Aglietta e Robert Boyer; a Escola Pós-Keynesiana, com autores como Hyman Minsky, Engelbert Stockhammer, Ismail Erturk e Thomas Palley; e a Escola Marxista, com autores como François Chesnais, Ben Fine, Gerald Epstein, José Carlos Braga, Costas Lapavitsas, Gérard Duménil e Dominique Lévy. (ANDRADE; FERES, 2018; SILVA, 2016).

Neste sentido, o escopo desde trabalho consistir-se-á na exposição de como o rentismo se expressa no Plano Real através do fortalecimento da acumulação financeira e do endividamento público como principal meio a partir do qual a República Rentista nasce e se sustenta. As políticas e medidas estabelecidas pelo Plano Real são as bases sobre as quais será analisado criticamente o plano, pois se tem como hipótese central que o tripé - câmbio, juros e inflação - afetou o setor financeiro e a dinâmica de acumulação no Brasil no sentido de fomentar a lógica rentística.

O Plano Real foi inserido num período histórico no qual a ideologia neoliberal gozava de seu auge, justificando a entrada massiva do capital internacional no país e fomentando as políticas do plano, pois, de fato, a inflação foi amenizada. Todavia, os custos para seu sucesso são os condicionantes ocultos que implicaram no aprofundamento do subdesenvolvimento e da dependência da economia brasileira (FILGUEIRAS, 2000). De tal forma que a problemática principal, aqui, se focará em questões como: Quem ganhou e quem perdeu no Plano Real? O Brasil se tornou uma República Rentista? Por que os juros brasileiros são os mais altos do mundo? Por que a dívida pública interna cresceu fortemente no pós-Plano Real?

Dito isto, nosso trabalho, além desta introdução, estruturar-se-á em três seções e uma conclusão, a saber: na primeira, pretendemos fazer uma breve exposição acerca das contribuições teóricas da abordagem marxista sobre o processo da financeirização, assim como de sua aplicação à realidade brasileira; em seguida, na segunda seção, exporemos o que foi e como foi feito o Plano Real; na terceira seção, buscaremos 
revelar o caráter rentista que assume a economia brasileira pós-Plano Real; e, por fim, exporemos as considerações finais.

\section{O FENÔMENO DA FINANCEIRIZAÇÃO EM SI E NO BRASIL}

Seguindo a abordagem de marxista, o processo de financeirização no capitalismo - a despeito de alguns aspectos de sua natureza já terem sidos identificados por Marx no século XIX - é um fenômeno que tem sua gênese a partir da segunda metade século XX. Nessa nova forma de reprodução, o ciclo D-D'2 do capital se universaliza de forma inexorável na lógica do capitalismo contemporâneo. Nesse processo, o movimento do capital portador de juros mostra-se como a forma geral do capital, isto é, dinheiro que gera mais dinheiro. A partir isso, as diferentes abordagens acerca do processo de financeirização na literatura marxista vão teorizar o fenômeno ponderando os aspectos que se julgam mais determinantes para a sua compreensão (SILVA, 2016).

Em Chesnais, o papel da concentração e centralização do capital é fundamental para compreender o processo de acumulação financeira, a partir da noção de autonomização do capital portador de juros. Nisto, a partir do processo de centralização do capital-dinheiro nas instituições financeiras, esta forma do capital vai assumindo um caráter autônomo em relação ao processo de produção, mas uma autonomia relativa, visto que o processo de criação de valor de limita ao capital industrial. Nesta nova realidade, o ciclo D-D' - em contraposição ao ciclo D-M-D’ - se enraizou no capitalismo mundial em todas as suas esferas. Logo, a "magia" de fazer dinheiro sem o intermédio do processo de produção assume a forma geral do capital e, por conseguinte, inaugura o fenômeno da financeirização no capitalismo contemporâneo. Assim, segundo Chesnais, o processo de financeirização trouxe duas consequências para a reprodução do capital: um crescimento na centralização do capital, gerado pelos

\footnotetext{
${ }^{2}$ Como destacado por Marx, a forma D-D’ é a forma mais geral e fetichista do capital. Nessa forma, o capital se apresenta de forma absoluta e autônoma ao processo de produção, como tendo a propriedade "mágica" de gerar mais dinheiro do dinheiro, isto é, o que Marx vai chamar de capital portador de juros. Neste sentido, ficam claras - à luz da elaboração de Marx - as contradições e ilusões desta forma aparente do capital, ou seja: que, na verdade, o D’ nada mais é que uma parcela da mais-valia produzida pelo capital - D - emprestado e empregado como capital (SILVA, 2016).
}

investidores institucionais, por meio de fusões e aquisições; e uma subordinação dos gestores-executivos aos interesses dos proprietários-acionistas, de modo a resultar num processo de financeirização crescente dos grupos industriais. Desta forma, essa nova relação entre finanças e indústria cristaliza a exterioridade do capital portador de juros e a natureza fictícia do capital acionário, assim como o poder do fetichismo do dinheiro nas relações sociais e econômicas (SILVA, 2016). Por conseguinte, a financeirização, na abordagem de Chenais (2016), diz respeito às finanças, como, também, à produção, a saber: se relaciona ao aumento do capital de investimento financeiro em circulação.

Já em Braga (2016), o processo de financeirização caracteriza-se como a "expressão geral das formas contemporâneas de definir, gerir e realizar riqueza no capitalismo" (BRAGA, 2016, p. 26). Neste sentido, segundo Braga (2016), surge uma nova relação entre o Estado e o mercado, por meio da emergência de um rentismo institucionalizado. Neste estado de coisas, a dificuldade de combinar liquidez e imobilização de capital deu origem a importantes inovações financeiras. Uma delas, talvez a mais importante, diz respeito ao princípio da securitização: "a predominância de títulos financeiros negociáveis, atendendo aos requisitos de mobilidade, liquidez e cobertura de risco, demandados pelos detentores de capital e investidores em geral" (BRAGA, 2016, p. 29). Tais inovações relacionam-se à desregulamentação dos sistemas financeiros por todos os governos do capitalismo central.

Além disso, neste processo, as relações entre Estado e mercado acentuam-se na medida em que o déficit público começa a ter um papel importante no aumento dos lucros bruto, livre de impostos, das corporações do capitalismo central. Aqui, o déficit público começa a assumir um caráter financeiro. Assim, as relações entre Estado - Banco Central e Tesouro - e mercado produz uma instabilidade crescente. De tal modo que a condução da política monetária, nesse estado de coisas, é condicionada pela necessidade além de controle da liquidez e da inflação - de bancar o déficit público e equilibrar o balanço de pagamento. Em outras palavras: combinam-se o desenvolvimento do sistema produtivo - ainda que viesado - com o avanço da capitalização financeira, num contexto de plena instabilidade (BRAGA, 2016). 
Em Duménil \& Levy, a caracterização do fenômeno da financeirização é enquadrada na noção de neoliberalismo. Aqui, o neoliberalismo deve ser entendido como uma nova ordem social na qual predomina o poder das finanças, a hegemonia de uma fração superior da classe capitalista e suas instituições financeiras sobre a economia e a sociedade em geral. Ademais, Duménil \& Levy fazem destaque para divisão qualitativa do lucro em "lucro da empresa", juros e dividendos para explicar o desenvolvimento das classes gerenciais, de modo ao conceito de salário, nesta nova configuração, mascarar a natureza concreta das relações sociais. Logo, a origem do neoliberalismo esteve associada a uma alta da remuneração do capital, mas não do ponto de vista dos lucros, e sim dos credores e acionistas, pois as finanças acabaram por elevar o seu peso econômico ao extrair juros e dividendos das corporações não financeiras (SILVA, 2016).

Já em Lapavitsas, o processo de financeirização reflete uma assimetria crescente entre a produção e a circulação capitalista durante as últimas três décadas, especialmente no componente financeiro da última. Neste sentido, segundo o autor, o sistema financeiro, ou as finanças, não é nem um complemento menor da acumulação, nem um parasita da economia capitalista, mas uma parte integrante do processo de acumulação. Aqui, a financeirização tem origem no crescimento assimétrico da circulação, no caso, financeira em relação à produção, e não teve como causa uma fuga de capitais para o mundo das finanças. Entre os aspectos mais gerais da financeirização, Lapavitsas destaca a crescente participação dos lucros financeiros no total dos lucros, o que evidencia a mudança no equilíbrio entre a acumulação real e financeira (SILVA, 2016).

No que diz respeito ao processo de financeirização no Brasil, independente da abordagem teórica utilizada acerca do processo de financeirização, pode-se afirmar que há um consenso na literatura que afirma que a economia brasileira, hoje, está inserida na lógica da financeirização do capitalismo contemporâneo. Neste sentido, segundo Lavinas, Araújo \& Bruno (2017), os anos de 1990 são essenciais para a caracterização do fenômeno da financeirização do Brasil, dado o crescimento exponencial do valor dos ativos financeiros em face da economia real neste período. No entanto, a gênese do processo de financeirização no Brasil remonta os anos 1970, avançando dali em diante. O surgimento do mecanismo de correção monetária nesse período faz surgir a chamada moeda indexada no setor bancário-financeiro na segunda metade dos anos de 1970. Assim, num contexto de crise fiscal e dívida externa, na década de 1980, possibilitar-se-á um avanço da concentração bancária sem precedente, sendo a inflação inercial o ponto de partida. Por meio da institucionalidade herdada dos anos 1970, o setor bancário-financeiro se desenvolverá a partir da acumulação rentista com base nos ganhos inflacionários derivados da rolagem da dívida pública, o que ficou conhecido como "ciranda financeira".

A partir do Plano Real, em 1994, a lógica de financeirização brasileira é alterada: sai-se dos ganhos inflacionários e entra-se na lógica de renda por elevados juros. Este processo vai proporcionar o aprofundamento do caráter financeiro da dívida pública brasileira e a progressão da lógica rentista-patrimonial para os serviços públicos e a seguridade social. Logo, como corolário, nas décadas de 1990 e 2000, a lógica rentista-patrimonial é estendida ao âmbito das empresas não financeiras e das famílias de alta renda. A financeirização pela renda de juros se consolida (LAVINAS; ARAÚJO; BRUNO, 2017).

Já em Bruno et al. (2011), o processo de financeirizção é visto em sua relação com o crescimento econômico. Aqui, as transformações - estabilização e liberalização - dos anos 1990 são fundamentais para caracterização do processo de financeirização da economia brasileira. A maior possibilidade de enriquecimento privado via alocações financeiras desencoraja o investimento produtivo em capital fixo, causando a baixa da taxa de crescimento econômico e aumento no desemprego estrutural. Ademais, vale destacar, que, na mesma direção da literatura referida acima, Bruno et al. (2011) apontam para a renda de juros e o endividamento público interno como as bases do processo de financeirização no Brasil.

Além disso, a partir do conceito de finance-led growth regime, isto é, "[...] caso em que o efeito-riqueza e o efeito-acelerador do investimento se revelam importantes para comandar a compatibilidade dinâmica entre produção e demanda [...]" (BRUNO et al., 2011, p. 735), os autores constatam, a partir da analise da evolução histórica de variáveis macroeconômicas, uma tendência de queda na parcela do lucro bruto macroeconômico destinada à formação bruta de capital fixo a partir de 1975. Tal fato, pois, reforça a hipótese de um regime de acumulação de padrão 
finance-led growth para o Brasil a partir o período referido. Ademais, os autores constatam que a taxa de financerização ${ }^{3}$ evolui numa correlação positiva com a parcela do lucro médio não investido na produção, reforçando, novamente, a hipótese do padrão finance-led growth. Esta ideia foi sustentada por meio de uma análise econométrica da relação entre o valor adicionado das instituições financeiras e o PIB brasileiro. Os dados apontam que, a partir de 1970, quanto maiores as taxas de inflação maior a participação do setor financeiro no valor adicionado total da economia brasileira. Tal processo se estendeu até o Plano Real, quando, num ambiente de abertura econômico-financeira e estabilização monetária, o processo de "[...] acumulação financeira vai se deslocar em direção aos derivativos e títulos de renda fixa conectados ao endividamento público, mas agora sob taxas reais de juros extremamente elevadas pelos padrões internacionais" (BRUNO et al., 2011, p. 735).

Nesta dinâmica, Bruno et al. (2011) identificam a dívida pública interna como principal eixo da acumulação rentista-patrimonial no período de 1991-2008, a despeito de assinalarem a relevância do endividamento público para o processo de financeirização dos anos 1980. Assim, segundo os autores, o Estado brasileiro estaria aprisionado pela lógica da financeirização:

A hipótese da financeirização como um processo resultante de condições macroeconômicas específicas implica considerar que a macroestrutura financeira atualmente vigente na economia brasileira aprisiona as finanças públicas porque comanda a política monetária e fiscal, formatando-a segundo as prerrogativas da acumulação rentista. Por essa razão, pode-se considerar de um lado a endogeneidade da dívida pública no modelo econômico neoliberal e, de outro, a exogeneidade da taxa Selic, uma vez que esta se converteu em instrumento-chave da política monetária restritiva inerente à financeirização por renda de juros. Isso significa que, contrariamente à vulgata acerca de um comportamento supostamente perdulário do Estado brasileiro, são os gastos financeiros, permanentemente realimentados por altíssimas taxas de juros reais, que respondem pelo

\footnotetext{
3 "Um indicador usual de financeirização no plano macroeconômico é construído pela razão entre o total de ativos financeiros não monetários (AF), dado pela diferença entre os agregados monetários M4 e M1 (deflacionados pelo IGP-DI) e o estoque total de capital fixo produtivo líquido de depreciação, isto é, máquinas e equipamentos mais construções não residenciais (Kprod)" (BRUNO et al., 2011, p. 737).
}

crescimento da dívida pública interna (BRUNO et al., 2011, p. 741).

Utilizando uma abordagem de economia política brasileira, Paulani (2012) vai dividir a história econômica brasileira em cinco fases acerca da relação da economia brasileira com o capitalismo global. Assim, o que podemos chamar de financeirização, segundo Paulani (2012), inicia-se na quarta fase, a saber: num regime de acumulação global no qual o Brasil é inserido por meio da demanda de empréstimos externos; e que vai resultar na crise da dívida externa dos anos 1980. Em seguida, na década de 1990, o processo de financeirização vai transformar o "[...] Brasil em plataforma internacional de valorização financeira, inaugurando, nos anos 1990, a quinta e atual fase da história da inserção da economia brasileira no processo mundial de acumulação" (PAULANI, 2012, p. 91). Assim, para Paulani (2012), nos anos de 1980, a partir da crise da dívida externa e da recorrente inflação, o Brasil é vítima do processo acelerado da financeirização do capitalismo contemporâneo. Já em 1990, a economia brasileira ingressa ativamente na financeirização. Todavia, o ingresso ativo na era da financeirização pressupunha duas providências: a abertura econômico-financeira e a estabilização monetária, sendo a primeira iniciada com o Governo Collor, e a segunda iniciada com o Plano Real. Nos anos 2000, a manutenção dos juros em níveis extremamente elevados e a lógica de superávits primários elevados consolidam a posição brasileira no capitalismo financeirizado.

Portanto, segundo Paulani (2012), a economia brasileira é hoje uma economia financeirizada, com o alto grau de centralização de capitais e completamente integrada ao capitalismo financeirizado mundial; o Estado brasileiro é a principal ferramenta dessa lógica rentista que reina na economia brasileira nas últimas décadas.

\section{O PLANO REAL}

O Plano Real surgiu num contexto de inflexão do capitalismo mundial. Conhecido popularmente como "neoliberalismo", tal fenômeno surge a partir dos fins dos anos de 1970 e torna-se um guia teórico e prático dos governos de quase todos os países do ocidente (FILGUEIRAS, 2000). De modo que "[...] 
o neoliberalismo assumiu a condição de hegemonia cultural, no sentido mais abrangente que este conceito possa ter" (FILGUEIRAS, 2000, p. 43). O neoliberalismo, pois, surge como uma reação teórica e política ao "Estado Keynesiano" presente nos EUA e Europa. As suas críticas não se distanciam das do liberalismo clássico, ou seja, defendia a soberania do mercado livre como condição para a liberdade econômica e política.

Portanto, a doutrina neoliberal se constrói em oposição a certa forma de intervenção estatal:

A decorrência dessa visão se expressa, do ponto de vista econômico, na recusa em aceitar o exercício de políticas ativas por parte do Estado; quer sejam macroeconômicas, no sentido de estimular em geral a atividade produtiva e o emprego, quer sejam políticas setoriais (industrial, por exemplo) e regionais. Em ambos os casos, segundo o neoliberalismo, o resultado final seria um desastre; porque a tentativa de impulsionar a economia, através de políticas monetárias e fiscais, terminaria apenas com mais inflação sem contudo reduzir o patamar de desemprego, enquanto o apoio a regiões e setores específicos implicaria ineficiências e desperdícios, em virtude da distorção que provocaria no "livre" funcionamento do mercado (FILGUEIRAS, 2000, p. 45).

Por conseguinte, à política econômica caberia a defesa da moeda - estabilidade de preços -, o cumprimento dos contratos e da livre concorrência. No plano internacional, a livre mobilidade de capitais e mercadorias, a abertura da economia e a livre circulação do capital financeiro ${ }^{4}$.

No âmbito da América Latina, a proposta neoliberal se consolidou no "Consenso de Washington", a saber: planos de estabilização por meio de valorização da moeda nacional e entrada de capitais especulativos; abertura da economia, com desregulação comercial e financeira; e reformas estruturais do Estado - com destaque para a privatização - a fim de minimizar sua participação na economia (FILGUEIRAS, 2000). Em suma, segundo Marini (1993), o neoliberalismo correspondia, na América Latina, à imposição dos

\footnotetext{
${ }^{4}$ Para uma maior discussão sobre o conceito de capital financeiro ver: SABADINI, M. S. Sobre o conceito de capital financeiro. Temporalis, [S.1.], v. 15, n. 30, p. 71-92, jan. 2016. Disponível em: <http://periodicos.ufes.br/ temporalis/article/view/10935>. Acesso em: 15 ago. 2019.

${ }^{5}$ Para maiores detalhes sobre o Consenso de Washington ver: BATISTA, P. N. O Consenso de Washington: a visão neoliberal dos problemas latino-americanos. Cadernos de Debates No 1 - Associações da CESP, São Paulo 1995.
}

interesses imperialistas a partir da nova realidade do capitalismo global.

Em termos materiais e políticos, o referido processo de inflexão no capitalismo global significou, a partir dos anos de 1990, a adesão de facto do neoliberalismo pela América Latina. No Brasil, tal processo se inicia a partir do Governo Collor (FILGUEIRAS, 2000). O ideário neoliberal é aplicado de forma efetiva com a união da abertura da economia com o processo de privatizações (CASTRO, 2011). As políticas de abertura e privatizações se enquadram no contexto da Política Industrial e de Comércio Interior (PICE), lançada no início do governo. As privatizações foram justificadas pelo governo com a "[...] crença de que haveria aumento na competição e, assim, aumento da eficiência [...]" (CASTRO, 2011, p. 136). No âmbito do comércio exterior, intensificou-se a liberalização das importações. Assim, acabaram as formas mais importantes de controle quantitativo de importação, para entrar o regime de controle tarifário, com alíquotas em queda.

Assim, como referido acima, Plano Real foi elaborado a partir de uma realidade ideológica de hegemonia do "neoliberalismo", razão pela qual as reformas neoliberais iniciaram-se já no Governo Collor. Neste sentido, a estrutura básica de concepção do Plano Real se resumiu em duas vertentes. A primeira foi o "Consenso de Washington", que trilhou para a América Latina os novos caminhos que deveriam ser seguidos por suas sociedades e economias, a partir das transformações reinantes no capitalismo mundial no período em questão. De modo que o dito consenso foi a base para a maioria dos planos de estabilização adotados na América Latina naquele período (FILGUEIRAS, 2000). O receituário básico de ajustamento das economias periféricas fora basicamente o seguinte:

[...] combate à inflação, através da dolarização da economia e valorização das moedas nacionais, associado a uma grande ênfase na necessidade do "ajuste fiscal". Acompanharam a realização de reformas do Estado - sobretudo privatizações e mudanças na seguridade social -, desregulamentação dos mercados e liberalização (internacionalização) comercial e financeira (FILGUEIRAS, 2000, p. 95).

A segunda vertente de referência para o Plano Real foi a experiência dos planos de estabilização passados, sobretudo o Plano Cruzado. Pois fora a 
partir deste que ganhou força o debate sobre o caráter inercial da inflação brasileira (FILGUEIRAS, 2000). Logo, a interpretação que identifica um caráter inercial na inflação brasileira foi de fundamental importância na base teórica do Plano Real, a despeito deste não interpretar a inflação brasileira como puramente inercial $^{6}$. Neste sentido, a proposta de combate à inflação inercial pela moeda indexada 7 foi fundamental na elaboração do Real.

Por tudo isso, pois, o Plano Real fundamentar-se-á na adoção de um novo padrão monetário e na implementação de um âncora cambial ${ }^{8}$ (MODENESI, 2005). De modo que plano foi concebido num programa de três fases distintas: "o ajuste fiscal, a criação da Unidade de Referência de Valor (URV) e instituição de uma nova moeda (o Real)" (FILGUEIRAS, 2000, p. 101). As duas ultimas fases - criação da URV e do Real - podem ser generalizadas em dois processos: a reforma monetária e a âncora cambial, respondendo pelas fases dois e três respectivamente. Assim, as duas primeiras fases do plano - o ajuste fiscal e a reforma monetária - podem ser consideradas corolário da fase posterior - âncora cambial -, em razão de que o ajuste fiscal e a eliminação da inércia inflacionária eram imprescindíveis para o sucesso da estabilidade, segundo seus formuladores (MODENESI, 2005). Além disso, como dito acima, as reformas de caráter neoliberal na organização do Estado se constituiu, segundo os formuladores do Plano, como um elemento indispensável para o resultado positivo do plano (FILGUEIRAS, 2000).

Por conseguinte, no que diz respeito à política fiscal, isto é, a primeira fase do plano, compreendia

\footnotetext{
6 "O diagnóstico do desajuste das contas públicas como (principal) causa da inflação brasileira torna o Plano Real, já na sua concepção, diferente de alguns de seus precursores nas décadas de 1980 e 1990. Ademais, embora todos os planos desde o Cruzado (1986) atribuíssem grande importância à necessidade de desindexação para a estabilidade dos preços, a proposta da URV era bastante original e bem mais complexa do que os congelamentos de preços propostos anteriormente." (CASTRO, 2011, p. 142).

${ }^{7}$ A proposta de combate à inflação pela moeda indexada é conhecida na literatura como a Proposta Larida, tal proposta consistiu basicamente: "[...] (i) na introdução de uma moeda indexada, que circularia paralelamente ao cruzeiro (instituindo-se um sistema bimonetário); (ii) no paulatino encolhimento da memória inflacionária, isto é, dos prazos de reajustes de preços. Ao final, retirar-se-ia de circulação a moeda velha e permaneceria a nova (o cruzeiro novo) em que os preços estavam estabilizados, isto é, livres da inflação. Neste instante, estaria consumada a milagrosa transposição de uma quase hiperinflação para uma economia estável" (MODENESI, 2005, p. 246). ${ }^{8}$ Vale destacar, que com a opção pela âncora cambial, num ambiente de abertura econômica, estava implícito no plano o aumento da dívida pública interna, mais precisamente numa segunda âncora baseada na dívida pública interna.
}

dois esforços fiscais: o Programa de Ação Imediata (PAI) e o Fundo Social de Emergência (FSE). O primeiro tinha por foco a redefinição da relação da União com os Estados e do Banco Central com os Bancos Estaduais e Municipais, além de um programa de combate à sonegação. O segundo previa a desvinculação de algumas receitas do governo federal, a fim de atenuar a rigidez dos gastos da União prevista na Constituição de 1988. Além disso, com o FSE o governo pretendia resolver a questão do financiamento dos programas socais brasileiros (CASTRO, 2011). Todavia, a eficácia dessas duas políticas - PAI e PSE - no longo prazo não se efetivou, pois a necessidade de financiamento do setor público (NFSP) cresceu fortemente no período de implantação do Plano Real: de uma média de 0,4\% do PIB, no período de 1991-1994, para uma média de 5,2\% do PIB durante o período de 1995-1998 (MODENESI, 2005). Em resumo, dois fatores contribuíram para o desequilíbrio fiscal verificado no período: “(i) a transformação do superávit operacional (de 2,9\% do PIB) em déficit operacional (de $0,2 \%$ do PIB); e (ii) a elevação da despesa com juros de 3,3\% do PIB para 5,0\%" (MODENESI, 2005, p. 302).

No que diz respeito à política monetária, o meio utilizado foi uma reforma monetária inspirada na proposta da moeda indexada - Proposta Larida. Na solução para a eliminação da inercia inflacionária, o processo residia na noção de que a interrupção da inflação deveria ser neutra do ponto de vista distributivo ${ }^{9}$, de modo que fazia-se necessário alinhar os preços relativos por meio de um indexador universal. Assim, cria-se, em $1^{\circ}$ de março de 1994, a Unidade Real de Valor - URV -, uma unidade de conta plenamente indexada (MODENESI, 2005). A URV poderia ser vista um com superindexador, cuja variação em cruzeiros reais fora definida por três índices: o IGP-M - Índice Geral de Preços de Mercado, o IPCA - Índice de Preços ao Consumidor Amplo - e o IPC - Índice de Preços ao Consumidor. A razão da escolha destes índices é que a evolução média deles se assemelhava à evolução histórica do câmbio, isto é, pretendia-se ancorar a URV ao dólar, de modo a já preparar a "âncora cambial" posterior. Desse modo,

\footnotetext{
${ }^{9}$ Num contexto de inflação inercial, uma interrupção brusca do processo inflacionário causaria efeitos distributivos de alto grau. Pois haveria uma transferência de renda dos agentes econômicos com contratos defasados para aqueles com contratos recentemente reajustados (MODENESI, 2005).
} 
pois, a URV eliminaria a memória inflacionária e, por conseguinte, o componente inercial da inflação. Na prática, a despeito do processo ter ocorrido com diferenças, o resultado foi a queda abrupta da inflação (FILGUEIRAS, 2000). Ademais, o governo optou por elevar as taxas reais de juros e aumentar as taxas de depósito compulsório da economia, após a introdução do Real, em virtude de que o fim da inflação lavaria a uma expansão natural de consumo, podendo inviabilizar a estabilidade (CASTRO, 2011).

Em sua terceira fase, a saber, na adoção da uma âncora cambial, a política cambial do Plano Real pode ser divida em quatro etapas: (i) de câmbio flutuante; (ii) de câmbio fixo; (iii) de banda cambial deslizante; e (iv) de banda cambial rastejante. Na primeira etapa - de câmbio flutuante -, executada de julho de 1994 a setembro de 1994, o Banco Central não interveio no mercado de câmbio. Nesta situação o Real se valorizou fortemente em virtude do influxo de capital externo, decorrente de uma situação de alta liquidez internacional. Na segunda etapa - câmbio fixo -, executada de outubro de 1994 a fevereiro de 1995, a taxa de câmbio nominal manteve-se, em boa medida, estável no valor de R\$ 0,84/US\$. O Banco Central realizou leilões de compras de dólares a fim interromper a valorização decorrente da etapa anterior. Com o advento da crise mexicana ao final de 1994 , os fluxos de capitais externos para as economias periféricas foram impactados negativamente. Nesta nova realidade, o Banco Central acabou forçado a adotar um sistema mais flexível de metas cambiais. Assim, o Banco central, em março de 1995, desvaloriza o Real em 5\% e adota uma banda larga de flutuação para o Real. A autoridade monetária começou a intervir diariamente no mercado de câmbio, manipulando a taxa de câmbio no interior da banda larga, de forma a estabelecer uma minibanda de flutuação para a moeda nacional. Em resumo, a Banco Central acabou por promover uma importante flexibilização no sistema cambial, se aproximando de uma banda deslizante10, expressando a terceira etapa da política cambial. Em meados de outubro de 1995 inaugura-se a quarta fase da política cambial, que manter-se-á inalterada até a crise de 1999. Nesse período, as minibandas

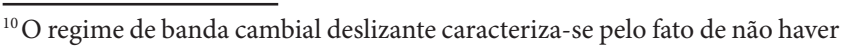
um comprometimento de se manter, indefinidamente, nem o ponto central nem a amplitude do intervalo de flutuação da moeda nacional (MODENESI, 2005).
}

assumiram uma inclinação positiva, de modo que as desvalorizações do Real convergiam para cerca de 0,6\% a.m. (MODENESI, 2005).

Ademais, o intervalo de flutuação do Real frente ao dólar estadunidense foi progressivamente aumentado, expressando duas mudanças no sistema cambial: "[...] (i) o ponto médio da banda cambial elevou-se paulatinamente; e (ii) a amplitude das bandas foi sendo progressivamente alargada" (MODENESI, 2005, p. 314). Assim, a quarta etapa da política cambial pode ser caracterizada pela adoção de uma banda rastejante ${ }^{11}$.

O mecanismo de choque nos preços domésticos por meio de uma âncora cambial funcionou da seguinte forma no Brasil: a economia nacional foi demasiadamente exposta pela referida abertura econômica e financeira, ao mesmo tempo em que o Real foi mantido artificialmente sobrevalorizado. Assim, parte crescente da demanda interna se deslocou para produtos importados, gerando uma "barreira" à capacidade do capital industrial doméstico de formar preços livremente. Logo, os produtores internos se viram forçados a praticar preços compatíveis com os dos similares importados. Em resumo:

Toda essa estratégia só foi possível porque apoiou-se numa política de juros altos, com a entrada no país de um grande fluxo de capitais de curto prazo, e num elevado nível de reservas cambiais, que correspondiam a 18 meses de importações - quando consideradas as médias mensais de 12 meses anteriores a julho de 1994 - e que atingiam, em junho de 1994, US \$ 40,5 bilhões no conceito de caixa, sendo que $70 \%$ desse montante foram acumulados durante a gestão de Cardoso no Ministério da Fazenda (FILGUEIRAS, 2000, p. 109).

Por fim, cabe destacar, que a despeito da aparente eficácia da âncora cambial no combate à inflação, duas variáveis não se comportaram, no Brasil, conforme previsto pela teoria econômica para o fenômeno, são elas: os juros e o déficit público. Pois, em geral, em países com alta inflação que adotam uma âncora cambial, a taxa de juros, não obstante o patamar inicialmente mais alto que o patamar internacional, tende a convergir para, com o passar do tempo, o nível internacional. Todavia, no Brasil a taxa de juros - em

\footnotetext{
${ }^{11}$ No regime de banda cambial rastejante a amplitude do intervalo de variação da taxa de câmbio evolui, sistematicamente, ao longo do tempo, de acordo com uma determinada regra (MODENESI, 2005).
} 
torno de $21 \%$, em média, em termos reais -, durante o período 1994-1998, manteve-se elevada, assim como o déficit público. Diante disto, pode-se dizer que os juros altos, durante a execução do Plano Real, funcionaram como uma segunda âncora de preços, a partir da qual a âncora cambial, nos últimos anos, foi perdendo sua relevância como uma âncora de preços (CASTRO, 2011).

Portanto, a partir do exposto, já torna-se possível a inferência - ainda que não tão concreta - de como o Plano Real fomentou o endividamento público e, por conseguinte, o processo rentístico. Ademais, a combinação de câmbio apreciado, abertura comercial e financeira e juros altos causarão consequências inexoráveis para economia brasileira, no que diz respeito ao desenvolvimento econômico, como se verá a seguir.

\section{A GÊNESE DA REPÚBLICA RENTISTA}

\section{A base ideológica do rentismo}

No que diz respeito ao regime fiscal, o consenso no Plano Real foi de que era necessário implementar uma gama de reformas estruturais na economia brasileira para se conseguir uma estabilização duradoura. A partir daí inicia-se a reformulação na concepção do regime fiscal brasileiro, de modo que com essa nova concepção o país precisava se mostrar comprometido com as políticas estabilizantes a fim de ganhar a confiança do mercado na manutenção de tal regime. Logo, a condução da política fiscal pressupunha uma institucionalidade rigorosa com o objetivo de gerar um superávit primário necessário ao equilíbrio nas contas públicas e de ganhar a confiança do mercado na manutenção das políticas vigentes (SANTOS; LOPREATO, 2016). Neste sentido, o Plano Real se habilitou a remodelar o "[...] aparato institucional e a formar um regime fiscal que atendesse às demandas tanto do ideário neoliberal quanto dos pressupostos da teoria macroeconômica dominante, do $\mathrm{NCM}^{12}$ ", (SANTOS; LOPREATO, 2016, p. 9).

\footnotetext{
${ }^{12} \mathrm{O}$ Novo Consenso em Macroeconomia (NCM) é a base teórica adotada no Brasil, a partir dos anos de 1990, para condução da política macroeconômica. O NCM ou Nova Síntese Neoclássica contempla as principais vertentes do pensamento ortodoxo no debate macroeconômico a partir de meados dos anos de 1980. É tratada como consenso ou síntese por reunir as contribuições da escola Novo-Clássica com as críticas e propostas dos Novos Keynesianos. Em resumo, na base deste ideário estão incorporados a otimização intertemporal e as expectativas racionais nos modelos macroeconômicos dinâmicos,
}

No que diz respeito à política monetária, esta foi ficou subordinada ao regime cambial. Ademais, como dito acima, o aumento das taxas de juros no imediato pós-plano era previsto em virtude da euforia do consumo esperado após a estabilização. Portanto, a restrição monetária vista no período esteve intimamente ligado à adoção do regime de metas cambiais. Ou seja, a sobrevalorização cambial, prevista no plano, impactava negativamente as contas externas do país. Consequentemente, o equilíbrio no balanço de pagamentos exigia um crescente influxo de capitais externos que, por sua vez, eram sustentados com a taxa de juros Selic em níveis demasiadamente elevados (MODENESI, 2005).

A partir do exposto, segue-se que toda a elaboração teórica do Plano Real, e as reformas institucionais inerentes a ele, convergiam para uma política ad infinitum de contração, restrição e estabilização. Pelo lado fiscal, isso é verificado pela adoção ao Novo Consenso em Macroeconomia, que impõe ao Estado a necessidade permanente de gerar superávits primários a fim de manter estável a relação dívida pública/PIB. Pelo lado monetário, a âncora cambial determina a política monetária, ou seja, a taxa de juros fica subordinada ao equilíbrio no balanço de pagamentos, fazendo com que o Banco Central perca o controle da política monetária. E pelo lado cambial, a câmbio é mantido sobrevalorizado a fim de controlar e inflação, causando, novamente, a necessidade do aumento na taxa de juros. Esta lógica de condução da política econômica no Brasil, iniciada com o Plano Real, vigorará até a crise de 1999, quando devido à forte pressão contra o Real o regime de âncora cambial é substituído pelo regime de câmbio flutuante. No lado monetário, o país adota o regime de metas de inflação. E pela ótica fiscal, segue-se a receita de manutenção dos superávits primários a fim de estabilizar a relação dívida pública/PIB. Na união dessas três óticas - cambial, fiscal e monetária - nasce a nova concepção de política macroeconômica no Brasil, a saber, "o tripé macroeconômico" (SANTOS; LOPREATO, 2016).

A análise mais profunda das consequências do dito "tripé macroeconômico" para a economia

\footnotetext{
em conjunção com a concorrência imperfeita e rigidez de preços e salários (SANTOS; LOPREATO, 2016). Neste regime “[...] as ações da política fiscal ficam submetidas ao comportamento daquelas variáveis que influenciam a trajetória da dívida e à volatilidade dos fluxos internacionais de capitais, fruto da avaliação do mercado sobre o risco de determinado país" (SANTOS; LOPREATO, 2016, p. 7).
} 
brasileira foge do escopo deste trabalho. No entanto, como será visto a seguir, a dinâmica rentística, cujo início é precisamente o Plano Real, não cessará com as trocas de governo pós-FHC. Portanto, a despeito da troca de regime cambial e monetário em 1999, as categorias fundamentais iniciadas pelo Plano Real não se anularam, mantendo responsabilidade do plano neste processo, mesmo após o fim do Governo FHC.

\section{A EXPRESSÃO EMPÍRICA DO RENTISMO}

Como já foi dito, a abertura econômica e a âncora cambial foram sustentadas por uma política monetária altamente restritiva, o que implicou na deterioração das principais variáveis macroeconômicas, exceto a inflação (FILGUEIRAS, 2000). Assim, observa-se que o movimento das variáveis econômicas antes e após o Plano Real demostra a referida deterioração e, por conseguinte, a sua relação com o rentismo.

Pela esfera externa, o rentimo pode ser verificado nos movimentos nas contas de serviços e de capitais - mais precisamente nas subcontas de rendas, empréstimos e amortizações. No caso das contas de serviços, a conta de lucros e dividendos, no acumulado de 1990-1994, saiu de um nível de US\$ 7,1 bilhões, para um nível de US\$ 17,4 bilhões no acumulado de 1994-1998 - um aumento de 144\%. Ainda na mesma conta, o movimento dos juros líquidos ficou estável, para os dois períodos citados. No entanto, no período pós-Real a tendência foi crescente, pois, a título de comparação, no acumulado de 2013-2016, a conta de juros líquidos foi de US\$ 85,0 bilhões, mais que o dobro do acumulado pós-Real - ver Tabela 1.

Tabela 1 - Montantes acumulados nas contas do balanço de serviços nos períodos pré e pós-Real e atualmente (US\$ milhões).

\begin{tabular}{l|l|l|l}
\hline Balanço de Serviços & $\begin{array}{l}\text { Pré-Real } \\
(90-94)\end{array}$ & $\begin{array}{l}\text { Pós-Real } \\
(95-98)\end{array}$ & $\begin{array}{l}\text { Mais atual } \\
(13-16)\end{array}$ \\
\hline Lucros e Dividendos & -7.145 & -17.441 & -85.160 \\
\hline Juros Líquidos & -40.240 & -40.482 & -85.046 \\
\hline
\end{tabular}

Fonte: adaptado de (FILGUEIRAS, 2000, p. 153) e (BRASIL, 2017a).

Pelo lado da conta de capitais, os empréstimos e financiamentos saíram de um patamar de US\$105,4 bilhões, no acumulado pré-Real - 1990-1994 -, para um patamar de US\$ 151,9 bilhões, no acumulado
pós-Real - 1994-1998. No caso das amortizações, o movimento ficou praticamente estável para os dois períodos, mas com tendência crescente no pós-Real (FILGUEIRAS, 2000); no acumulado 2013-2016 as amortizações chegaram a US\$ 254,8 bilhões, enquanto os empréstimos e financiamentos ${ }^{13}$, para o mesmo período, foram de US\$259,8 bilhões, ou seja, um saldo de apenas US\$ 4,9 bilhões (BRASIL, 2017a).

Portanto, a progressão das rendas enviadas ao exterior após o Plano Real - seja nos primeiros anos ou atualmente - é inegável. Cabe destacar que nível de lucros e dividendos enviados ao exterior em 2016 superou o valor acumulado nos quatro primeiros anos pós-Real; no caso dos juros líquidos, em 2016 atingiu-se mais da metade do valor acumulado nesses quatro primeiros anos.

Na Tabela 2, abaixo, é possível ver o crescimento das rendas enviadas, decorrente dos investimentos externos feitos no Brasil, desde 1990. Considerando os investimentos reais - IED - e os investimentos financeiros - em carteira e outros investimentos -, ver-se que esses cresceram, entre 1990 e $2010,566,1 \%$. E, em 2016, a despeito da crise brasileira, foi constatada uma despesa na ordem de US\$ 52 bilhões, valor 269,7\% superior ao visto em 1995.

Tabela 2 - Pagamento de rendas decorrentes da existência de investimentos externos - Brasil - por quinquênio 1990-2015 e 2016 (US\$ bilhões).

\begin{tabular}{l|l|l|l|l|l|l|l}
\hline Ano & 1990 & 1995 & 2000 & 2005 & 2010 & 2015 & 2016 \\
\hline $\begin{array}{l}\text { Despesas com } \\
\text { rendas de } \\
\text { investimentos } \\
\text { - total }\end{array}$ & 12,7 & 14,2 & 21,3 & 29,0 & 84,6 & 54,7 & 52,5 \\
\hline $\begin{array}{l}\text { Despesas com } \\
\text { rendas de } \\
\text { investimentos } \\
\text { diretos }\end{array}$ & 1,9 & 3,3 & 4,2 & 11,0 & 62,1 & 28,5 & 28,7 \\
\hline $\begin{array}{l}\text { Despesas com } \\
\text { rendas de } \\
\text { investimentos } \\
\text { em carteira }\end{array}$ & 0,4 & 4,9 & 9,4 & 12,5 & 18,1 & 19,0 & 14,4 \\
$\begin{array}{l}\text { Despesas } \\
\text { com rendas } \\
\text { de outros } \\
\text { investimentos }\end{array}$ & 10,4 & 6,0 & 7,7 & 5,4 & 4,3 & 7,1 & 9,3 \\
\hline
\end{tabular}

Fonte: adaptado de (apud PAULANI, 2013, p. 238) e (BRASIL, 2017a).

\footnotetext{
${ }^{13}$ A metodologia de elaboração do Balanço de Pagamentos alterou-se desde 1994. Portanto a rubrica "Empréstimos e Financiamentos" está sendo interpretada aqui como equivalente a "Empréstimos e títulos de LP negociados no mercado externo", constate na publicação atual do Banco Central.
} 
No âmbito interno, o rentismo pode ser verificado no aumento do endividamento público. Pois, em função da política de juros altos, a dívida líquida interna, que correspondia a $21,5 \%$ do PIB em 1994 , salta para $36,5 \%$ do PIB em 2000 , chegando a $61,5 \%$ do PIB em 2016; a dívida líquida total, que em 1994 correspondia a $30,0 \%$ do PIB, chegou a $45,5 \%$ do PIB em 2000, chegando a 46,2\% em 2016 - ver Tabela 3 abaixo.

Tabela 3 - Dívida Líquida do Setor Público e NFSP - conceito nominal - por triênio 1994-2015 e 2016 (\% do PIB).

\begin{tabular}{l|l|l|l|l|l|l|l|l|l}
\hline & 1994 & 1997 & 2000 & 2003 & 2006 & 2009 & 2012 & 2015 & 2016 \\
\hline Dívida interna & 21,5 & 27,8 & 36,5 & 43,2 & 47,6 & 49,7 & 45,1 & 54,8 & 61,5 \\
\hline Dívida externa & 8,5 & 4,0 & 9,0 & 11,0 & $-1,2$ & $-8,8$ & $-12,9$ & $-19,2$ & $-15,4$ \\
\hline Dívida total & 30,0 & 31,8 & 45,5 & 54,3 & 46,5 & 40,9 & 32,2 & 35,6 & 46,2 \\
\hline Resultado primário & $-5,21$ & 0,88 & $-3,24$ & $-3,23$ & $-3,15$ & $-1,94$ & $-2,17$ & 1,85 & 2,48 \\
\hline Juros nominais & 29,88 & 4,62 & 6,61 & 8,41 & 6,72 & 5,13 & 4,44 & 8,36 & 6,49 \\
\hline NFSP & 24,67 & 5,50 & 3,37 & 5,18 & 3,56 & 3,18 & 2,26 & 10,2 & 8,98 \\
\hline
\end{tabular}

Fonte: Adaptado de (GIAMBIAGI, 2011, p. 173 e 189) e (BRASIL, 2017b).

Assim, como dito anteriormente, essa trajetória crescente do déficit público fora causada pela estratégia adotada pelo Plano Real, ou seja:

A principal razão para o crescimento da dívida pública brasileira, como já foi afirmado, está na estratégia de abertura econômica, que provocou desequilíbrios nas contas externas do país. Para conseguir ajustar essas contas, optou-se por atrair capitais externos, com base no lançamento de títulos públicos que pagavam uma taxa de juros muito superior à praticada nos mercados internacionais. A remuneração desses títulos provocou fortes pressões sobre o orçamento público (GOMES, 2007, p. 196).

Em função desta dinâmica, o esforço fiscal do governo em gerar superávits primários foi anulado pelo nível elevado da taxa de juros na economia brasileira no período em questão. Pois, como pode ser visto na Figura 1 a seguir, a despeito do governo, no período de 1996-2005, ter por objetivo gerar sucessivos superávits primários, os mesmos nunca conseguiram compensar a trajetória nominal dos juros pagos pelo setor público. A partir disto, pois, o caráter financeiro do déficit público pode ser inferido, isto é: "As finanças públicas deterioraram-se progressivamente, em razão da necessidade se manter a abertura econômica e financeira [...]" (GOMES, 2007, p. 198). De modo que a ligação dos mercados financeiros com as finanças públicas acaba por impulsionar o rentismo em favor dos investimentos no setor produtivo (GOMES, 2007).

Figura 1 - Evolução do superávit primário e dos juros nominais pagos pelo setor público - 1996-2005 (\% do PIB).

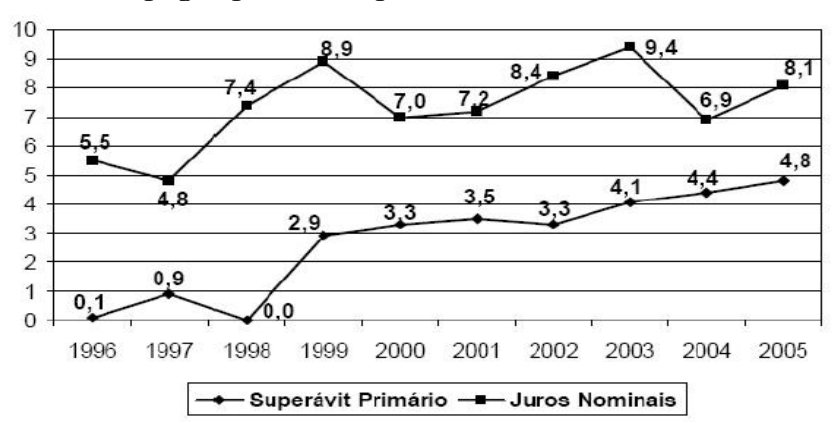

Fonte: Banco Central (apud GOMES, 2007, p. 200).

Portanto, o Plano Real ao aderir à abertura econômica e à âncora cambial cria as bases essenciais sobre as quais o rentismo no Brasil se sustentará. Pois, como visto, seja pelo lado externo - com as rendas enviadas ao exterior -, como pelo lado interno - com os juros pagos pelo setor público, após o Real, o sistema financeiro se hegemonizou. Essa dinâmica de desequilíbrio externo e fragilização financeira do Estado brasileiro pode ser vista na Figura 2 abaixo: 
Figura 2 - Abertura econômica, desequilíbrio externo e endividamento público.

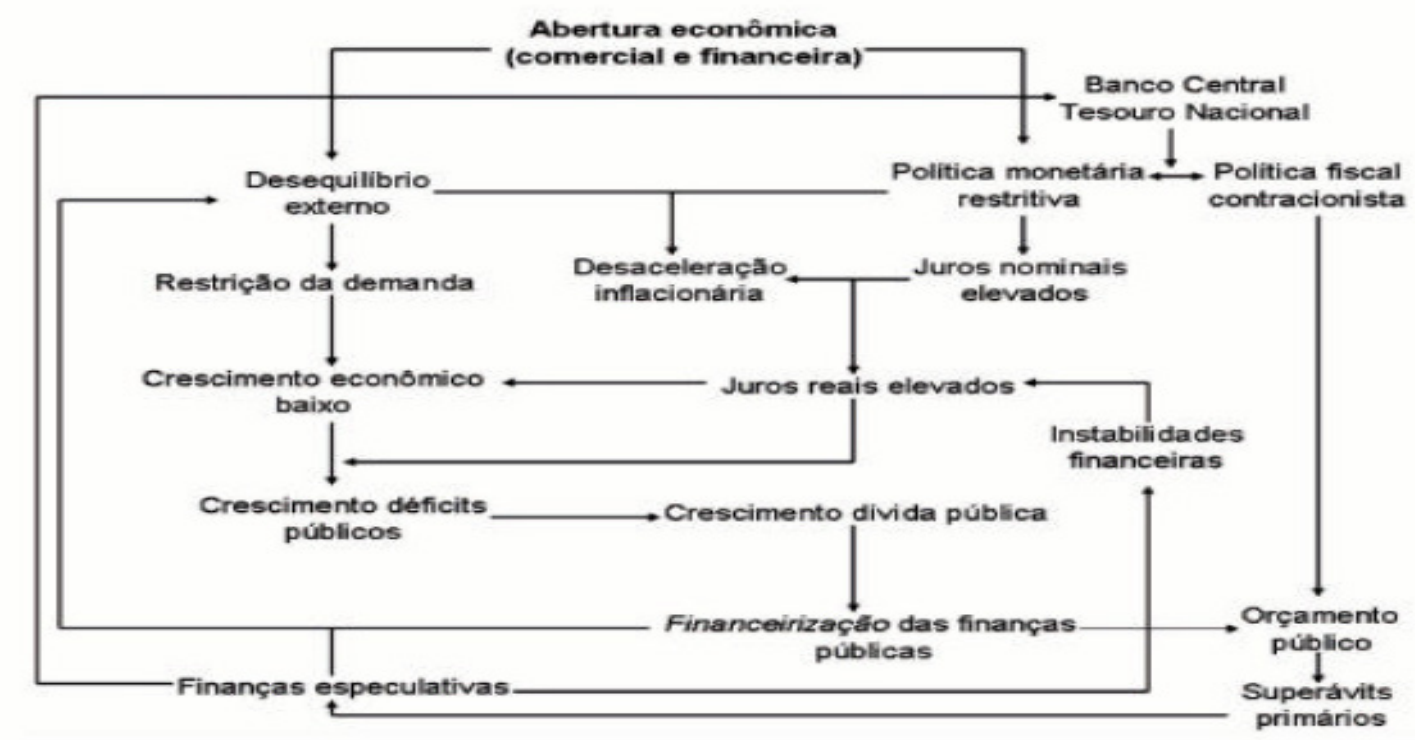

Fonte: (GOMES, 2007, p. 198).

\section{A HEGEMONIA FINANCEIRA PÓS-REAL}

Como foi dito acima, toda a estratégia teórica do Plano Real fomentou a política de juros altos. Assim, em resultado deste processo ver-se-á um fortalecimento do sistema financeiro como um todo, de tal modo que em sua expressão econômica esse processo se materializa no rentismo crescente a partir do Plano Real; e em sua expressão política ele se fundamenta no próprio fortalecimento do sistema financeiro no Brasil. Desse modo, o fortalecimento da classe financeira a partir do Plano Real se expressa, inicialmente, a partir da maior concentração de capital no setor financeiro e nos ganhos dos bancos com o plano (OURIQUES, 1997). De modo que o fortalecimento do sistema financeiro do geral, no período pós-Plano Real, pode ser verificado em seu conjunto da seguinte forma:

Socorro ao sistema financeiro e subsídios para fusão e incorporação de instituições financeiras; manutenção de altas taxas de juros, títulos públicos com liquidez e rentabilidade; fundos de investimentos com alta rentabilidade; liberação de tarifas bancárias; diminuição da carga tributária sobre os bancos; privatização dos bancos estaduais; desregulamentação do sistema financeiro; banqueiros nos ministérios e nos partidos de sustentação do governo; farta contribuição dos grupos financeiros para as campanhas políticas nas eleições municipais, estaduais e federais, influindo maciça contribuição financeira à campanha do presidente eleito em 1994; bloqueio às iniciativas de criar uma Comissão Parlamentar de Inquérito sobre o sistema financeiro nacional [...] (MINELLA, 1997, p. 165)

Em consequência disso, com o processo de privatizações em curso, o setor bancário brasileiro, a partir de 1995, começou a concentrar-se. O total de instituições que em 1994 chagara a 273 se reduziu para 233, em 1998 (FILGUEIRAS, 2000). Além disso, cabe destacar que o movimento de concentração não cessará em 1998, pois em 2016 o número de instituições registrado decresceu $27 \%$ ante 1998 . No caso dos bancos públicos, viu-se uma grande diminuição; em junho de 1994 o total de bancos públicos era de 40 instituições, enquanto que dezembro de 1998 o total diminuiu para 30 bancos; e, por fim, em 2016, o total de bancos públicos na economia brasileira foi de 10 instituições (BRASIL, 2017c). Por conseguinte, como expressão deste processo, as cinco maiores, que em 1994 concentravam em si $50 \%$ dos ativos totais do sistema bancário brasileiro, em 2002 atingiram uma participação de $50,6 \%$ nos ativos totais do setor ${ }^{14}$. Mais atualmente, pode ser ver o aumento exponencial da centralização do capital bancário; pois em 2002, os

\footnotetext{
${ }^{14}$ KOERICH, M. C. R. M. A influência das regulamentações governamentais sobre o sistema bancário brasileiro após a implementação do Plano Real. 2004. Monografia (Graduação) - Departamento de Ciências Econômicas, Centro Sócio-Econômico, Universidade Federal de Santa Catarina, 2004. Disponível em: <https://repositorio.ufsc.br/handle/123456789/121814>. Acesso em: 13 jul. 2019.
} 
cinco maiores bancos no Brasil, que representavam $50,6 \%$ dos ativos totais, atingem a incrível marca de $80 \%$ de participação nos ativos totais do segmento em $2016^{15}$.

Analisando mais precisamente a esfera do rentismo, a política de juros altos, a fim de sustentar a sobrevalorização do Real, fez com que o setor financeiro ganhasse muito nos quatro anos do Governo FHC. De modo que os bancos ganhavam por duas vias: pela valorização inicial do Real em 1994 - tomando empréstimos em dólares e aplicando em Reais - e pela especulação com os títulos públicos (FILGUEIRAS, 2000).

Ademais, é possível verificar que o sistema bancário brasileiro continuou se apoiando nas receitas de operações com Títulos e Valores Mobiliários após o Governo FHC. De modo que aí já se vê inicialmente os impactos do Plano Real no desenvolvimento do rentismo no Brasil, pois para o período de 2007-
2015, vê-se que as receitas com os títulos e valores mobiliários - TVM - só perdem para as receitas com operações de crédito, sendo TVM a segunda maior receita por intermediação financeira- Tabela 4 abaixo.Outro ponto importante diz respeito ao peso das receitas com TVM no total das receitas por intermediação financeiras, quanto houve aumento da Selic a partir de 2013. Nas palavras de Oliveira (2017):

[...] as receitas de TVM foram muito importantes para o crescimento das receitas de intermediação financeira tanto em 2014 como em 2015. Essa expansão das receitas de TVM do CB I decorreu tanto da maior exposição patrimonial dos bancos em relação a essas operações, como da trajetória de expansão da taxa Selic, que, depois de ter atingido seu nível nominal mais baixo entre outubro de 2012 e abril de 2013 (7,25\% a.a.), encerrou $2014 \mathrm{em} 11,75 \%$ ao ano (a.a.) e 2015 em 14,25\% a.a. (OLIVEIRA, 2017, p. 16).

Tabela 4 - Resultado bruto da intermediação financeira do conglomerado bancário I ${ }^{16}$ - 2007-2015 (R\$ bilhões de 2013).*

\begin{tabular}{|c|c|c|c|c|c|c|c|c|c|}
\hline & 22007 & 22008 & 22009 & 22010 & 22011 & 22012 & 22013 & 22014 & 22015 \\
\hline $\begin{array}{l}\text { Receitas de intermediação } \\
\text { financeira }\end{array}$ & 394,8 & 510,8 & 505,8 & 522,8 & 603,6 & 566,2 & 547,0 & 622,5 & 701,6 \\
\hline Operações de crédito** & 243,9 & 283,7 & 251,6 & 285,0 & 338,1 & 335,2 & 329,5 & 362,3 & 395,3 \\
\hline Arrendamento mercantil & - & 35,8 & 83,9 & 70,2 & 48,6 & 40,0 & 31,7 & 20,8 & 11,5 \\
\hline TVM & 124,3 & 152,0 & 144,1 & 134,4 & 166,4 & 160,5 & 146,6 & 190,9 & 234,3 \\
\hline Derivativos & 4,5 & $(7,7)$ & 11,5 & $(2,0)$ & $(3,1)$ & $(7,8)$ & 3,3 & 5,1 & 1,8 \\
\hline Operações de câmbio & 7,5 & 31,9 & 7,7 & 13,3 & 12,5 & 10,4 & 12,4 & 14,3 & 28,6 \\
\hline Aplicações compulsórias & 14,6 & 15,0 & 6,9 & 21,8 & 41,2 & 27,0 & 21,7 & 27,4 & 27,8 \\
\hline $\begin{array}{l}\text { Operações de venda ou } \\
\text { de transferência de ativos } \\
\text { financeiros }\end{array}$ & - & 0,0 & 0,1 & 0,1 & 0,0 & 0,8 & 1,7 & 1,7 & 2,3 \\
\hline
\end{tabular}

Fonte: adaptado de (OLIVEIRA, 2017, p. 12).

Notas: ${ }^{*}$ Deflator: IPCA

** Até o $1^{\circ}$ semestre de 2008 , inclui operações de arrendamento mercantil.

${ }^{15}$ Para maiores detalhes de ver: BRASIL. Banco Central do Brasil. IF.data. 2017d. Disponível em: <https://www3.bcb.gov.br/ifdata/index.html >. Acesso em: 13 nov. 2017.
Dito isto, é razoável inferir que o meio principal a partir do qual o rentismo no Brasil se sustenta é o setor financeiro - mais precisamente, o setor bancário. Pois, como visto, com as reformas implementadas a partir do Plano Real, o setor bancário brasileiro consolida-se em regime de oligopólio e classe hegemônica. Além disso, a despeito de o Brasil ter abandonado a

\footnotetext{
${ }^{16}$ De acordo com o Banco Central o Conglomerado Bancário I mais Instituições Independente I integram o Consolidado Bancário I. O Conglomerado Bancário I refere-se aos conglomerados financeiros que detêm pelo menos uma instituição do tipo banco comercial ou banco múltiplo com carteira comercial (OLIVEIRA, 2017).
} 
âncora cambial em 1999 e ter adotado o "tripé macroeconômico", as estruturas materiais e institucionais criadas, a partir do Plano Real, permitiram a gênese e a posterior manutenção do rentismo, em suas diversas formas - rendas enviadas ao exterior e juros devidos pelo mercado e pelo setor público.

\section{A DÍVIDA PÚBLICA COMO MEIO DE DOMINAÇÃO DA CLASSE FINANCEIRA}

Como já visto anteriormente, a dívida pública interna pós-Plano Real teve um comportamento crescente. Os motivos desta evolução são diversos, no entanto, dentre os principais, podem-se citar os seguintes: (i) emissão de dívida para esterilização do capital externo que fluía para o Brasil atraído pelo processo de privatização e alto nível da taxa de juros
(GOMES, 2007); (ii) o saneamento dos Estados e Municípios (FERREIRA, 2005); (iii) o nível alto da taxa de juros (FERREIRA, 2005); (iv) e com os recursos destinados ao PROER ${ }^{17}$ (MINELLA, 1997). De modo que até o Banco Central brasileiro reconheceu tal processo, quando em maio de 1996 afirmou que os fundos de investimentos no país estavam proporcionando consideráveis ganhos reais para os investidores e que a participação dos títulos públicos nos fundos estava crescendo, em detrimento dos títulos privados (MINELLA, 1997). Logo, pois, pós-Plano Real houve um aumento nas operações com títulos públicos federais, de modo que o saldo das operações com títulos e de mercado aberto passou de um patamar de $\mathrm{R} \$ 62,2$ bilhões em 1994, para R $\$ 787,5$ bilhões em 2003 Tabela 5 -, ou seja, foi multiplicada por 12 .

Tabela 5 - Títulos Públicos Federais e Operações de Mercado Aberto: participação percentual por indexador - por triênio $1994-2015$ e 2016

\begin{tabular}{lccccccccc}
\hline Índice de correção & 1994 & 1997 & 2000 & 2003 & 2006 & 2009 & 2012 & 2015 & 2016 \\
\hline Saldo - R\$ milhões & 62,2 & 252,9 & 506,7 & 787,5 & $1.153,5$ & $1.826,2$ & $2.414,1$ & $3.544,7$ & $4.017,8$ \\
Câmbio* & 9,4 & 15,5 & 22,5 & 20,5 & $-1,0$ & 0,5 & 0,6 & 12,5 & 2,5 \\
TR & 22,8 & 9,1 & 4,7 & 1,7 & 2,1 & 0,9 & 0,5 & 0,3 & 0,3 \\
Over/Selic** & 15,9 & 35,1 & 52,7 & 46,6 & 38,1 & 27,4 & 17,4 & 5,6 & 19,5 \\
Pré-fixado & 53,2 & 41,3 & 14,9 & 11,6 & 34,2 & 25,8 & 32,7 & 30,7 & 27,4 \\
Índice de Preços & 12,4 & 0,3 & 6,0 & 12,6 & 21,4 & 21,9 & 28,2 & 25,6 & 24,7 \\
Outros & 5,5 & 0,6 & 0,1 & 0,0 & 0,0 & 0,0 & 0,0 & 0,0 & 0,0 \\
OMA*** & $-22,1$ & $-2,0$ & $-0,8$ & 7,1 & 5,2 & 23,1 & 20,6 & 25,2 & 25,6 \\
\hline Total & 100,0 & 100,0 & 100,0 & 100,0 & 100,0 & 100,0 & 100,0 & 100,0 & 100,0 \\
\hline
\end{tabular}

Fonte: elaboração própria com base em: (BRASIL, 2017b).

Notas: ${ }^{\star}$ Com swap

** Com swap

*** Operações de Mercado Aberto

Ainda na Tabela 5, é possível verificar, pós1994, o aumento da participação dos títulos públicos indexados à Selic e ao câmbio, ou seja, variáveis nas quais o Plano Real se utilizou para o processo de estabilização - política de juros altos e âncora cambial. Ademais, expressando o aumento da relação das classes financeiras com a dívida pública, ver-se-á que concomitantemente com o aumento no estoque de títulos público emitidos, a participação dos bancos e do setor financeiro no referido estoque aumentará. Pois de 1994-1999 houve um aumento na participação de títulos públicos na carteira dos bancos; de 1994 a 1998 tal participação evoluiu de 4,9\% para $24 \%$ no caso dos bancos públicos, e de $8,6 \%$ para $26,5 \%$ no caso dos bancos privados nacionais; de forma que em dezembro de 2000 os títulos públicos representavam $38,2 \%$ da carteira de títulos do setor bancário brasileiro. De modo que em dezembro de 2002, dos R\$ 623,2 bilhões de títulos públicos em circulação, $\mathrm{R} \$ 216,0$ bilhões estavam nas carteiras dos bancos e R \$ 200,11 bilhões em fundos de investimentos financeiros, que são administrados pelos bancos. Portanto, neste período, $67 \%$ dos títulos públicos em circulação estavam sob controle direto ou sob influência dos bancos, em

\footnotetext{
${ }^{17}$ Programa de Restruturação Bancária.
} 
outras palavras; estavam sob o controle das classes financeiras (FERREIRA, 2005).

Tal dinâmica não cassará com o fim do Governo FHC, pelo contrário, houve progressão. De modo que, analisando o sistema bancário nos dias atuais, vê-se que os lucros dos maiores bancos no Brasil seguiram uma tendência crescente - a despeito de oscilações conjunturais. Assim, para o ano de 2016, viram-se resultados expressivos nos resultados dos cinco maiores bancos no Brasil ${ }^{18}$, a despeito da recessão econômica brasileira ter-se prolongado em 2016 A partir do relatório do $\operatorname{DIEESE}^{19}$ (2017), para o ano de 2016, o resultado operacional dos cinco maiores bancos no Brasil chegou ao montante de $\mathrm{R} \$ 95,8$ bilhões, um aumento, anualizado, de 204,8\%; o lucro líquido dos cinco maiores, para 2016, chegou ao valor de $\mathrm{R} \$ 59,6$ bilhões, uma queda de $12,1 \%$ em face do ano anterior. Ademais, corroborando a tese da relação íntima do setor bancário brasileiro com os títulos - em maior parte títulos públicos -, em 2016 o resultado das operações com títulos e valores mobiliários - TVM - atingiu o montante de R \$229,4 bilhões, consolidando-se como a segunda maior receita dos maiores bancos no Brasil.

Assim, pois, em síntese de todos os fatores mencionados até aqui - no que diz respeito ao rentismo - chega-se ao ponto máximo da expressão rentística no Brasil, a saber, no sistema da dívida ${ }^{20}$. Em suma, os principais fatores constitutivos que garantem a manutenção do sistema da dívida, segundo a Auditoria Cidadã da Dívida, são:

- Elevadíssimas taxas de juros: praticadas sem justificativa técnica, jurídica, econômica ou política;

- A ilegal prática do anatocismo: incidência contínua de juros sobre juros;

- A irregular contabilização de juros como se fosse amortização da dívida, burlando-se o artigo 167, III, da Constituição Federal;

- As escandalosas operações de swap cambial realizadas pelo $\mathrm{BC}$ em moeda nacional, garantindo o risco de variação do dólar de forma sigilosa;

\footnotetext{
${ }^{18}$ Banco do Brasil, Bradesco, Caixa Econômica Federal, Itaú e Santander.

${ }^{19}$ Departamento Intersindical de Estatística e Estudos Socioeconômicos.

${ }^{20}$ Terno que a Auditoria Cidadã da Dívida usa para designar toda a estrutura de privilégios - políticos e econômicos - do sistema financeiro na sua relação com a dívida pública. Em resumo: "[...] na prioridade absoluta aos pagamentos financeiros da dívida, em detrimento de direitos humanos e sociais de toda a nação" (FATTORELLI, 2017, p. 33).
}

- Remuneração da sobra do caixa dos bancos por meio das sigilosas "operações compromissadas" que já superam R $\$ 1,15$ trilhão em 2017;

- Emissão excessiva de títulos para formar "colchão de liquidez";

- Emissão de títulos para comprar dólares e aplicar em Reservas Internacionais, e para repassar ao BNDES;

- Reclassificação estatística de títulos dívida interna como se fosse dívida externa, com assunção de obrigação financeira adicional;

- Pagamento de títulos antigos, da década de 1940 apesar do Plano Brady.

- Prejuízos do Banco Central (FATTORELLI, 2017, p. 18).

Portanto, a partir do exposto, pôde se ver, ainda que de forma genérica, o caráter oneroso do sistema da dívida, no que diz respeito ao interesse da coletividade. Ademais, a despeito das diversas conjunturas e mudanças com as quais a economia brasileira lidou desde o Plano Real, não seria pretensioso afirmar que o Plano Real, com todo o seu arcabouço econômico-político-ideológico, criou - e fortaleceu algumas já existentes - as bases para o fortalecimento da classe financeira. Fortalecimento este que veio a se materializar no rentismo financeiro sustentado pelo sistema da dívida. Em outras palavras, pode-se dizer que o sistema da dívida é um mecanismo que se sustenta a partir da relação íntima do setor financeiro com o Estado brasileiro, sendo tal relação uma relação de dominação da classe financeira para com Estado.

\section{CONSIDERAÇÕES FINAIS}

A partir do exposto, pôde-se compreender melhor a relação entre o Plano Real e a gênese do rentismo no Brasil. Neste sentido, podemos citar quatro fatores principais, iniciados ou fortalecidos pelo Plano Real, que fomentaram o rentismo brasileiro: (i) a abertura econômica iniciada por Collor e fortalecida com o Plano Real; (ii) a mitologia de uma moeda forte num país dependente e subdesenvolvido - expressada na sobrevalorização do Real frente ao dólar mantida, a partir do Plano Real, até a crise de 1999; (iii) em relação com esta última, a manutenção da taxa básica de juros num nível demasiadamente alto ao longo de todo o Governo FHC; (iv) e o incentivo à entrada 
de capital estrangeiro a fim de equilibrar o balanço de pagamentos e/ou adquirir ativos nacionais com o processo de privatizações do Governo FHC.

Assim, foi por meio, em maior parte, dos quatro fatores mencionados que, a partir do Plano Real, viu-se o crescimento da dinâmica rentística no país. Logo, neste contexto, com base no que foi exposto neste trabalho, podem-se citar três formas principais de manifestação do rentismo, verificadas a partir de 1994, no Brasil, a saber: (i) no aumento das rendas enviadas ao exterior na forma de juros, lucros e dividendos; (ii) na concentração e centralização do capital bancário, possibilitando, a partir do Plano Real, uma tendência progressiva de receitas neste setor, mesmo em situação de recessão econômica; (iii) e, por fim, em relação com a anterior e sendo a manifestação mais expressiva, no crescimento exponencial da dívida pública interna, com o capital bancário sendo seu maior beneficiário.

Além disso, o caráter rentístico que se procurou expor-se aqui caminha em convergência com a literatura que trabalha com o tema da financeirização no Brasil. Pois, como visto acima, os anos de 1990 e, sobretudo, o Plano Real são condicionantes essenciais para a compreensão do processo de financeirização no Brasil. Neste sentido, o rentismo, com base na renda de juros e na dívida pública interna é o pilar fundamental para compreensão do referido fenômeno no Brasil, algo em comum visto na literatura exposta. Ademais, por outro lado, cabe destacar que nosso trabalho não esgota o tema do rentismo no Brasil, visto que o conceito de rentismo compreendido aqui abrange a esfera financeira assim como a esfera territorial- no sentido de renda da terra.

Assim, a partir do estado de coisas ao qual o Brasil chegou hoje, seria razoável, dentre todas as formas de rentismos coexistentes na economia brasileira, eleger o rentismo via renda de juros e dívida pública o que tem sido mais prejudicial aos interesses das classes populares. Pois o sistema da dívida, desde o Plano Real, vem transferindo recursos crescentes do Estado brasileiro para o pagamento de juros e amortização da dívida. Desse modo, deste o Plano Real o governo central tem se esforçado crescentemente - fomentado a partir do "tripé macroeconômico"- para gerar superávits primários a fim de manter a relação dívida/PIB estável. Todavia, o resultado, como foi exposto, não vem sendo eficaz, pois viu-se a DPMFi ${ }^{21}$ saltar de R\$ 63 bilhões, em 1994, para mais de R\$ 4 trilhões em 2016.

Dito isto, identificamos o caráter financeiro da dívida pública pós-Plano Real como o meio principal de sustentação da República Rentista. Daí que, analisando em retrospectiva a evolução da economia brasileira desde 1994 até hoje, a república brasileira pode ser caracterizada como uma República Rentista.

Assim, concluímos que não parece haver razão alguma, senão para manter a riqueza concentrada nas mãos dos rentistas em detrimento dos trabalhadores, que justifique o atual estado de coisas no país, no que diz respeito ao sistema da dívida. Portanto, assim como o Plano Real surgiu como um modelo "moderno" que colocaria o Brasil na competitividade global, depois de passados 25 anos do plano e vistas suas consequências econômicas e sociais, faz-se necessário, num horizonte de superação da dependência e do subdesenvolvimento, de medidas para a extinção do rentismo e, por consequência, para a inauguração de um novo padrão de desenvolvimento nacional para o Brasil.

Portanto, ainda que sejam indicações genéricas, podemos citar dois horizontes - que, por sua vez, estão ligados com a superação da dinâmica rentística no Brasil - a partir dos quais se poderá pensar mais concretamente a questão do desenvolvimento econômico e social brasileiro: primeiro, num âmbito mais limitado, a defesa absoluta de uma auditoria da dívida pública, prevista na Constituição Federal brasileira de 1988 e representada socialmente pela associação sem fins lucrativos da Auditoria Cidadã da Dívida; e, segundo, num âmbito mais geral, uma reforma bancária, de natureza estatizante, a fim desconcentrar e descentralizar o sistema bancário brasileiro.

\section{REFERÊNCIAS}

ANDRADE, L. B.; FERES, L. P. Financeirização e os sentidos do desenvolvimento: aspectos teóricos e as reformas de mercadol no caso brasileiro. In: XXIII Encontro Nacional de Economia Política, 2018, Niterói, RJ. Disponível em: $\quad<$ https://sep.org.br/anais/Trabalhos\%20para $\% 200 \% 20$ site/Area\%206/86.pdf>. Acesso em: 26 jun. 2019.

BRAGA, J. C. S. A financeirização da riqueza: a macroestrutura financeira e a nova dinâmica dos capitalismos

\footnotetext{
${ }^{21}$ Dívida Pública Mobiliária Federal interna.
} 
centrais. Economia e Sociedade, Campinas, v. 2, n. 1, p. 25-57, 11 fev. 2016. Disponível em: <https://periodicos. sbu.unicamp.br/ojs/index.php/ecos/article/view/8643298>. Acesso em: 06 jul. 2019.

BRASIL. Banco Central do Brasil. Série histórica do Balanço de Pagamentos - $6^{\mathrm{a}}$ edição do Manual de Balanço de Pagamentos e Posição de Investimento Internacional (BPM6). 2017a. Disponível em: <http://www.bcb.gov.br/ htms/infecon/Seriehist_bpm6.asp>. Acesso em: 01 nov. 2017.

BRASIL. Banco Central do Brasil. Séries Temporais. 2017b. Disponível em: <https://www3.bcb.gov.br/sgspub/ localizarseries/localizarSeries.do?method=prepararTelaLoc alizarSeries>. Acesso em: 13 nov. 2017.

BRASIL. Banco Central do Brasil. Relatório de Evolução do SFN. 2017c. Disponível em: <http://www.bcb.gov. br/?revsfn201612>. Acesso em: 03 nov. 2017.

BRUNO, M. et al. Finance-Led Growth Regime no Brasil: estatuto teórico, evidências empíricas e consequências macroeconômicas. Revista de. Economia Política, São Paulo, v. 31, n. 5, p. 730-750, 2011. Disponível em: $<$ http://www.scielo.br/scielo.php?script=sci_arttext\&pid $=$ S0101-31572011000500003 $>$. Acesso em: 07 jul. 2019.

CARDOSO, F. H. Plano Real respondeu a uma demanda da sociedade, diz FHC. Agência Câmara, 07 jul. 2009. Repostagem de Noéli Nobre. Disponível em: <http://www2. camara.leg.br/camaranoticias/noticias/137241.html> . Acesso em: 17 ago. 2019.

CASTRO, L. B. Privatização, Abertura e Desindexação: A Primeira Metade dos Anos 90 (1990-1995). In: GIAMBIAGI, Fabio et al. Economia Brasileira Contemporânea [1945 2010]. 2. Ed. Rio de Janeiro: Elsevier, 2011.

CHESNAIS, F. Finance Capital Today: Corporations and Banks in the Lasting Global Slump. Leiden; Boston: Brill, Historical Materialism, Book Series, 2016.

DIEESE. Desempenho dos Bancos 2016 - Lucros permanecem elevados, mas bancos promovem intensa reestruturação. 2017. Disponível em <http://www.dieese. org.br/sitio/buscaDirigida?tipoBusca $=$ tipo\&valorBusca $=$ des empenho+dos+bancos>. Acesso em: 10 nov. 2017.

FATTORELLI, Maria Lucia. Relatório Específico de Auditoria Cidadâ da Dívida No $1 / 2017$. 2017. Disponível em: $\quad<$ http://www.auditoriacidada.org.br/relatorios-daauditoria-cidada/>. Acesso em: 11 nov. 2017.

FERREIRA, Alceu Conceição. Os donos da dívida: um enfoque sóciopolítico da dívida pública interna durante o governo FHC. Florianópolis, 2005. Dissertação (Mestrado) - Universidade Federal de Santa Catarina, Centro de Filosofia e Ciências Humanas. Programa de Pós-Graduação em Sociologia Política Disponível em: $<\mathrm{http} / / / w w w . t e d e$. ufsc.br/teses/PSOP0214.pdf $>$. Acesso em: 02 ago. 2019.
FILGUEIRAS, L. A. M. História do plano real: fundamentos, impactos e contradições. São Paulo: Boitempo, 2000.

FRANCO, G.. 20 ANOS DO PLANO REAL. Época NEGÓCIOS, 2014. Entrevista concedida a Marcela Bourroul. Disponível em: $<$ http://20anosdoreal. epocanegocios.globo.com/entrevistagustavofranco.html $>$. Acesso em: 17 ago. 2019.

GIAMBIAGI, F. Estabilização, Reformas e Desequilíbrios Macroeconômicos: Os Anos FHC (1995-2002). In: GIAMBIAGI, Fabio et al. Economia Brasileira Contemporânea [1945 - 2010]. 2. Ed. Rio de Janeiro: Elsevier, 2011.

GOMES, F. G. ACUMULAÇÃO DE CAPITAL VIA DÍVIDA PÚBLICA: CONTRIBUIÇÃO PARA UMA CRÍTICA À RAZÃO DA CRISE FISCAL. 2007. Tese (Doutorado) - Núcleo de Pós-graduação em Administração, Escola de Administração, Universidade Federal da Bahia. Salvador, 2007.

LAVINAS, L., ARAÚJO, E. BRUNO, M. -Brasil: vanguarda da financeirização entre os emergentes? Uma análise exploratóriall. Texto para discussão - IE / UFRJ, n.032. Rio de Janeiro, 2017. Disponível em: <http://www. ie.ufrj.br/index.php/listar-td/textos-para-discussao-2017/ brasil-vanguarda-da-financeirizacao-entre-os-emergentesuma-analise-exploratoria>. Acesso em: 07 jul. 2019.

MARINI, R. M. La crisis teórica. In. : MARINI, Ruy Mauro. América Latina: integración y democracia. Caracas: Nueva Sociedad, 1993.

MINELLA, A. C. Elites financeiras, sistema financeiro e Governo FHC. In. : RAMPINELLI, W. J.; OURIQUES, N. D. No fio da navalha: critica das reformas neoliberais de FHC. São Paulo: Xamã, 1997.

MODENESI, A. M. Regimes monetários: teoria e a experiência do real. Barueri: Manole, 2005.

NETTO, J. P. Introdução ao estudo do método de Marx. São Paulo: Expressão Popular, 2011.

OLIVEIRA, G. C. O DESENPENHO DO SISTEMA BANCÁRIO NO BRASIL NO PERÍODO RECENTE (2007-2015). Texto para discussão / Instituto de Pesquisa Econômica Aplicada - Ipea, Brasília - Rio de Janeiro, n. 2327, 2017. Disponível em: <http://www.ipea.gov.br/portal/index. php?option $=$ com_content $\&$ view $=$ article $\&$ id $=30964$ :td2327-o-desempenho-do-sistema-bancario-no-brasil-noperiodo-recente-2007-2015\&catid $=397: 2017 \&$ directo ry $=1>$. Acesso em: 07 nov. 2017.

OURIQUES, N. D. A sedução revolucionária e o Plano Real. In. : RAMPINELLI, W. J.; OURIQUES, N.D. No fio da navalha: critica das reformas neoliberais de FHC. São Paulo: Xamã, 1997. 
PAULANI, L. M. A Inserção da economia brasileira no cenário mundial: uma reflexão sobre a situação atual à luz da história. Boletim de Economia e Política Internacional - IPEA, Brasília, jun. 2012. Disponível em: <http:// repositorio.ipea.gov.br/handle/11058/4554>. Acesso em: 07 jul. 2019.

PAULANI, L. M. Acumulação sistêmica, poupança externa e rentismo: observações sobre o caso brasileiro. Estudos Avançados, São Paulo, v. 27, n. 77, p. 237-264, 2013. Disponível em: <https://www.revistas.usp.br/eav/article/ view/53965>. Acesso em: 01 nov. 2017.

SANTOS, F. A.; LOPREATO, F. L. C. O novo consenso em macroeconomia no Brasil: a política fiscal do Plano Real ao segundo Governo Lula. Textos para Discussão / IE/ Unicamp, Campinas, n. 267, 2016.

SILVA, E. M. A economia política da dominância financeira: acumulação de capital e rentismo no capitalismo contemporâneo. 2016. 117 f. Dissertação (Mestrado em Economia Política) - Programa de Estudos Pós-Graduados em Economia Política, Pontifícia Universidade Católica de São Paulo, São Paulo, 2016. 